\title{
Srovnání geografické reprezentativity vlád České republiky a Slovenské republiky ${ }^{1}$
}

\author{
Petr Dvořák ${ }^{2}$ - Milan Podmaník - Michal Pink \\ Katedra politologie, Fakulta sociálních studií Masarykovy univerzity, Brno
}

\begin{abstract}
Comparison of Geographical Representativeness of Governments of the Czech Republic and the Slovak Republic. This study analysis geographical representativeness of governments in the Czech Republic and in the Slovak Republic. It claims, that both countries differ in the position of the capital, as within the Czech Republic its dominant position is declining, while in Slovak republic it retains this position. This dominance is also underlined by the centralization of other districts around Bratislava. On the other hand a larger number of regions are more ideally represented or overrepresented in the Czech republic than in the Slovak republic. It can therefore be stated that the two countries differ in terms of geographical representativeness of individual governments.

Sociológia 2021, Vol. 53 (No. 1: 26-48)

https://doi.org/10.31577/sociologia.2021.53.1.2
\end{abstract}

Key words: Geographical representativeness; descriptive representation; the Czech Republic; the Slovak Republic; government; regions; districts

\section{Úvod}

V roce 1993 se na politickém spektru objevily dva nové státy, a to Česká republika a Slovenská republika. U prvního jmenovaného státu došlo k ustanovení dvoukomorového parlamentu, který tvoří Poslanecká sněmovna Parlamentu České republiky (PS ČR) a Senát. Oproti tomu byl na Slovensku ustanoven jednokomorový parlament s Národní radou Slovenské republiky (NR SR). I přes to, že se v obou zemích využívá volební systém poměrného zastoupení kandidátních listin, lze nalézt rozdílnosti i v nastavení volebních obvodů. Volby do dolní komory parlamentu České republiky se konají od roku 2002 ve čtrnácti volebních krajích, které nahradily původních osm krajů, přičemž počet mandátů pro volební kraj je určený počtem odevzdaných platných hlasů $\mathrm{v}$ jednotlivých krajích. Jednotlivé kraje se tak liší v počtu přerozdělovaných mandátů, ale na druhou stranu je zaručeno, že bude zvolen reprezentant každého kraje (skrze bydliště). Jiné nastavení lze nalézt ve Slovenské republice, kde se od roku 1998 konají volby v rámci jednoho volebního obvodu, což nepodporuje rovnoměrnějš́ zastoupení poslanců skrze jejich bydliště.

Po představení teorie politické reprezentace, zaměřené na jeden $\mathrm{z}$ jejich typů, tedy deskriptivní reprezentaci, se přes stanovení sledovaného období,

\footnotetext{
${ }^{1}$ Rádi bychom na tomto místě poděkovali anonymním oponentům za cenné připomínky a komentáře. Současně mohl text vzniknout díky vstřícnosti České grantové agentury, která podpořila projekt Životopisy a výkon politiků v České republice a na Slovensku (GA 18-15700S).

2 Korespondence: Mgr. Petr Dvoř́k - Mgr. Milan Podmaník - doc. Mgr. Michal Pink, Ph.D., Katedra politologie, Fakulta sociálních studií Masarykovy univerzity, Brno, Joštova 218/10, 60200 Brno, Česká republika. E-mail: Dvořák 413425@mail.muni.cz; Podmaník-427155@mail.muni.cz; pink@ fss.muni.cz
} 
územních celků a jednotek dostaneme $\mathrm{k}$ analýze jednotlivých států. V první části se zaměřme na bydliště ministrů ve vládách obou států $\mathrm{s}$ ohledem na pozici hlavního města. $\mathrm{V}$ práci vycházíme ze závěrư ${ }^{3}$, které poskytli autoři Latner a McGann ve své studii zaměřené na Nizozemí a Izrael, když zjistili, že oproti regionům v blízkosti hlavního města mají periferní regiony a regiony se silnou identitou, stejně jako hlavní město, větší zastoupení v parlamentu (2005). Zároveň vycházíme ze závěrů Renáty Mikešové a Tomáše Kosteleckého (2016), zabývajících se proporcionalitou zastoupení okresů/krajů v PS ČR po roce 1989. Důležitým zjištěním je ztráta výlučného postavení okresů s velkými městy a Prahy, která v letech 1992 - 1998 dosahovala výraznějš́i nadreprezentace, která však v následujících letech postupně klesala. Zároveň v rámci dvou posledních volebních období zmiňované analýzy, tedy 2010 a 2013 lze vidět určitý nárůst počtu nezastoupených okresů (6), stejně jako okresů s výraznější nadreprezentací (okres Tábor, Most, Benešov a Jablonec nad Nisou). Potvrdila se i ztráta dominance Prahy a okresů s největšími městy. V rámci krajů docházelo v prvních volbách po roce 1989 k výraznější nadreprezentaci Prahy a podreprezentaci Libereckého a Karlovarského kraje. Tato nesourodost však zmizela po roce 2002 a volební reformě spočívající v nastolení čtrnácti volebních obvodů dle samosprávných krajů (Mikešová Kostelecký 2016: 367-370).

Tibor Madleňák (2019) popisuje proporcionalitu zastoupení okresů/krajů v NR SR od roku 1998. V rámci Slovenské republiky je patrná výraznější nadreprezentace Bratislavského kraje na úkor ostatních krajů, a to v rámci všech parlamentních voleb od roku 1998. Rozdíly u ostatních krajů nejsou natolik výrazné, i když lze sledovat menší zastoupení východního Slovenska oproti západnímu Slovensku, což je nejvíce patrné u Prešovského kraje s největším počtem obyvatel, avšak nejmenším zastoupením mezi kraji ve třech volbách. I v rámci okresů je nejvýrazněji nadreprezentována Bratislava, avšak lze vypozorovat postupné posilování okresů v jejím okolí (Senec, Pezinok a Malacky). Výraznější nadreprezentace byla pozorována u okresu Dunajská Streda, která byla dle Madleňáka způsobena etnickým faktorem spojených se stranami SMK a Most-Híd. V ostatních krajích ${ }^{4}$, dominovaly krajská města, avšak ne v rámci všech sledovaných období, přičemž pozice Košic se nelišila od ostatních krajských měst. Zároveň lze konstatovat, že dominují spíše okresy na západě Slovenska stejně jako na úrovni krajů. $\mathrm{K}$ výraznější nadreprezentaci, která nebyla způsobena menší velikostí okresu, lze zařadit ještě okresy v blízkosti krajských měst (Madleňák 2019: 487-491).

Je tak patrné, že se Česká republika i Slovenská republika liší co do složení parlamentních komor (PS ČR a NR SR) z hlediska míry proporcionality jednot-

\footnotetext{
3 Do dnešního dne neexistuje studie, která by řešila geografickou reprezentativitu členů vlád. Existují však práce zaměřené na poslance (Latner - McGann 2005; Madleňák 2019; Mikešová - Kostelecký 2016).

4 Až na Prešov, kde došlo k nadreprezentaci ve volbách v roce 2010.
} 
livých okresů i krajů. V České republice lze hovořit o proporcionálním zastoupení většiny okresů i krajů s klesajícím významem Prahy a velkých měst. Oproti tomu ve Slovenské republice je situace rozdílná, když většího zastoupení dosahují okresy i kraje západního Slovenska. Výrazné nadreprezentace oproti ostatním okresům se těší i krajská města a jejich okolí, z kterých výrazněji vyčnívá Bratislava. Obdobná situace je patrná i v rámci krajů. Předložená práce se tak snaží zjistit, zda se rozdílnosti v rámci proporcionality zastoupení v rámci parlamentních komor Slovenské a České republiky projeví i při sestavování jednotlivých vlád jako celku ${ }^{5}$. Není tak důležité, které strany nominují jednotlivé ministry, ale zajímá nás vláda jako celek.

\section{Teorie deskriptivní reprezentace}

Když se zaměříme na pojem reprezentace, lze hovořit o zpřítomnění něčeho, co není v danou chvíli fakticky prítomné (Pitkin 1972: 8-9; Dovi 2017). Samotným prostředkem pro výběr zástupců, kteří by hájili určité zájmy, jež považuje volič za podstatné, jsou volby. S tím úzce souvisí teorie politické reprezentace, jejíž základy položila Hanna Pitkin v knize The Concept of Representation, ve které autorka rozlišuje čtyři základní typy politické reprezentace. První z nich formalistická reprezentace - je spojena převážně se vztahem mezi voličem a reprezentantem, přičemž je důležité, zda se jedná o vztah pověření (zástupce má oprávnění jednat jménem svých voličů) nebo zodpovědnosti (zástupce zastupuje své voliče s vědomím toho, že se bude zodpovídat za své činy (Pitkin 1972: 38-59)). Dále lze hovořit o reprezentaci konání, tedy zaměření se na konkrétní kroky reprezentanta, jeho činnost (Pitkin 1972: 112-143), přičemž Pitkin hovoří o důležitosti určité míry svobody reprezentanta při rozhodování a vylučuje tak mechaničnost jeho konání (Pitkin 1972: 152).

Pro účely naší práce je však důležitá reprezentace zpřítomňování dělící se na tzv. symbolickou a deskriptivní. O symbolické reprezentaci můžeme hovořit jako o propojení osob s něčím, co není fyzicky skutečné, jedná se o pocitovou stránku založenou na vnitřním nastavení každé osoby. Typickým př́íkladem jsou hymny či vlajky, kdy osoba díky ní cítí určitou sounáležitost s národem jako celkem (Pitkin 1972: 92-111). Naopak u deskriptivní reprezentace je důležité faktické složení reprezentujícího tělesa dle určitých znaků společnosti tak, aby byly zastoupeny relevantní charakteristiky společnosti (Pitkin 1972: 6061). Tyto charakteristiky jsou spojeny s identitou každého voliče a může se tak stát, že i když má nějaká osoba reprezentanta skrze své pohlaví, nemusí tomu tak být ještě skrze svou etnicitu (Goodin 2004: 460). Mezi charakteristiky, kte-

\footnotetext{
5 Důležité je zmínit, že se členy vlád stávají zvolení poslanci, což může mít vliv na geografíckou reprezentativitu vlád, a některá zjištění tak budou obdobná jako u geografické reprezentativity Poslanecké sněmovny nebo Národní rady. Na druhou stranu je počet ministrů výrazně menší, než je tomu u členů NR SR nebo PS ČR a výsledky tak mohou být v některých aspektech odlišné.
} 
ré by měly být dostatečně zastoupeny $\mathrm{v}$ zastupitelském tělese tak, aby zahrnoval důležité názory společnosti (Dovi 2010: 3; Phillips 1998: 65; Pitkin 1972: 89), lze zařadit pohlaví, věk, barvu pleti, profesi, místo narození, členství v etnické, náboženské skupině či určité oblasti zájmu nebo schopnosti (Squires 1996: 81-82; Caul 1999: 94; Mansbridge 1999: 629; Atkenson 2003: 1052-3; Krook - O'Brien 2010: 255, 262).

Co se týče jedné z těchto charakteristik, tedy bydliště, je dokázáno, že voliči vnímají, odkud kandidát ve volbách pochází (Campbell - Cowley 2014), stejně jako že se s kandidáty se stejným bydlištěm lépe identifikují (Key 1949). V českém prostředí navíc autoři Voda a Pink (2009) dokázali na př́ípadu voleb do Poslanecké sněmovny v roce 2006, že kandidát, který kandiduje mimo kraj svého bydliště, má podporu rozprostřenou po celém obvodu, kdežto lídr kandidující v kraji svého bydliště má největší podporu v rámci místa svého bydliště. Stejně tak řada autorů hovoří o „nadržování“ oblastem okolo bydliště politika při tzv. porcování medvěda, (pork barrel politics), tedy situaci, kdy jsou rozdělovány veřejné peníze na určité projekty (Grossman - Helpman 2005; Latner McGann 2005; Hána 2013). Z výše popsaného je tedy zřejmé, že bydliště politiků je důležité jak z hlediska politické reprezentace, tak i konkrétních politických kroků. Osoba pocházející z určité oblasti může do zastupitelského tělesa přinášet názory a postřehy typické pro danou oblast, které by $\mathrm{v}$ př́ípadě jejího nezvolení zůstaly skryty (Powell 2004). V případě vlády mají její členové také přimý vliv na návrhy zákonů, které přijímá vláda jako celek a jsou dále postoupeny ke schválení parlamentu. Jedná se tedy o další politickou arénu, ve které mohou osoby př́mo reprezentovat oblasti, ze kterých pocházejí, at' už formou hlasování či možností přednést vlastní argumenty k připravovaným zákonům. $\mathrm{Z}$ tohoto hlediska je tedy důležité, odkud pochází členové vlád.

\section{Metodologie}

V práci zjišstujeme, zda se Česká republika a Slovenská republika liší v geografické reprezentativitě $\mathrm{v}$ rámci jednotlivých vlád jako celku. $\mathrm{V}$ rámci srovnání jednotlivých vlád pracujeme s údaji od roku 1996 na české straně, do kterých spadá jedenáct vlád ${ }^{6}$ a na slovenské straně s osmi vládami ${ }^{7}$ spadajícími do období po roce 1998. Seznamy jednotlivých ministrů byly získány na stránkách Úřadu vlády Slovenské republiky (Úrad vlády SR 2020) a Vlády České republiky (Vláda ČR 2020). U druhé Babišovi vlády a vlády Igora Matoviče je pracováno se seznamem členů jednotlivých vlád $\mathrm{k}$ 31. 10. 2020. U jednotlivých vlád je sledováno bydliště všech osob, které se v době trvání vlády vystřídaly

\footnotetext{
6 Konkrétně se jedná o vlády: Klausova II., Zemanova, Špidlova, Grossova, Paroubkova, Topolánkova I. a II., Nečasova, Sobotkova a Babišova I. a II. Třem úřednickým vládám (Tošovského, Fischerova, Rusnokova) je věnována samostatná podkapitola.

7 Jedná se o vlády: Dzurindova I. a II., Radičové, Ficova I., II. a III., Pellegriniho a Matoviče.
} 
na ministerských postech. Jednotlivé vlády se lišily co do počtu svých členů, zároveň však byla každá osoba započítávána pouze jednou, a to i v situacích, kdy $\mathrm{v}$ rámci jedné vlády vystř́ídala více postů. Údaje o bydlišti ministrů byly získány z kandidátních listin dostupných na stránkách Českého statistického úřadu, konkrétně stránek volby.cz (Volby.cz) př́padně ze stránek justice.cz (justice.cz). Data o slovenských ministrech byla následně získána ze stránek Štatistického úradu Slovenskej republiky, konkrétně ze stránek volby.statistics.sk (Volby.statistics.sk.) nebo z veřejně dostupných zdrojů (Úrad vlády SR). Údaje o počtu obyvatel v rámci krajů v obou zemích byly získány ze stránek statistických úřadů jednotlivých států a to $\mathrm{k} 31$. 12. př́slušných roků (ČSÚ; StatDat).

Pro analýzu geografické reprezentativity byla zvolena metoda Latnera a McGanna (2005), kterou využili pro své závěry i Mikešová s Kosteleckým (2016: 364) či Tibor Madleňák (2019: 485-486). Geografická reprezentativita

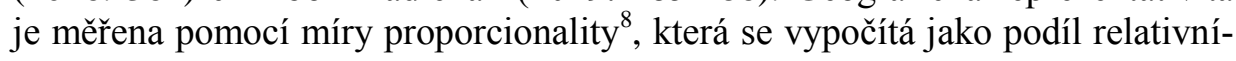
ho počtu ministrů $\mathrm{s}$ bydlištěm $\mathrm{v}$ daném kraji a relativního počtu obyvatel $\mathrm{v}$ daném kraji ${ }^{9}$. Pro výčet geografické reprezentativity jednotlivých vlád byl využit vyšší územní celek a to kraj, jelikož v rámci vlády je omezený počet míst, který nemůže automaticky zahrnout všechny okresy, které by se tak ve většině př́padů rovnaly nule. $\mathrm{V}$ práci bude také sledováno, zda jednotliví ministři pochází z okresů krajských měst, prŕípadně kolik okresů nebylo doposud zastoupeno $\mathrm{v}$ žádné vládě. $\mathrm{V}$ př́padě, že se míra proporcionality v kraji rovná $0,8-1,2$, obyvatelé daného kraje jsou ve vládě zastoupeni proporcionálně jejich počtu. Hodnoty menší jak 0,8 znamenají podreprezentaci, hodnoty vyšší jak 1,2 nadreprezentaci (Mikešová - Kostelecký 2016). V rámci České republiky nalezneme čtrnáct samosprávných krajủ, které se liší svojí velikostí a počtem obyvatel, přičemž i v období před rokem 2002 je pracováno s počtem čtrnácti krajü ${ }^{10}$. $\mathrm{V}$ prŕpadě okresů $\mathrm{v}$ textu pracujeme se 76 okresy, které jsou doplněny o Prahu. Používáme tedy obdobnou strategií, jakou zvolili Mikešová a Kostelecký (2019: 369-370). Naopak ve Slovenské republice se osm krajů odlišuje ve své rozloze daleko méně, než je tomu $\mathrm{v}$ př́ípadě České republiky ${ }^{11}$. Text dále v př́ípadě Slovenska počítá se 71 okresy. Slovensko má ve skutečnosti okresů 79, avšak pět bratislavských okresů (Bratislava I.-V.) a pět košických (Košice

\footnotetext{
${ }^{8}$ Míra proporcionality $=$ (počet ministrů s bydlištěm v kraji/počet ministrů ve vládě) $/$ (počet obyvatel kraje/počet obyvatel ČR/SR.

9 Pracujeme s počtem obyvatel k roku, ve kterém se konaly poslední volby do PS ČR/ NR SR. U voleb do NR SR v roce 2020 pracujeme s počtem obyvatel ke konci roku 2019.

10 Nejméně lidnatý kraj Karlovarský má kolem 300 tisíc obyvatel, Liberecký kraj nad 400 tisíc obyvatel, přičemž kraj Středočeský, Jihomoravský, Moravskoslezský a Praha má více jak milion obyvatel (ČSÚ).

${ }^{11}$ Nejméně lidnatý kraj Trnavský a Trenčianský má pod 600 tisíc obyvatel, přičemž kraj Prešovský a Košický má nad 800 tisíc obyvatel (StatDat).
} 
I.-IV. plus okolí Košice-okolí) bylo sloučeno a v práci vystupují pouze jako okres Bratislava a okres Košice.

\section{Míra proporcionality jednotlivých vlád České republiky od roku 1996}

V následující části se zaměříme na proporcionalitu jednotlivých vlád z hlediska krajů od roku 1996 (viz graf č. 1). Z výsledků je zřejmé, že kraje s nejmenším počtem obyvatel nejsou ve vládách zastupovány téměr žádnými představiteli, jelikož $\mathrm{v}$ rámci všech vlád lze nalézt pouze jednoho ministra $\mathrm{z}$ Libereckého kraje v Nečasově vládě (,dokonalá“ reprezentace, hodnota 0,83 ) a žádného z kraje Karlovarského. Nejmenší kraje tak mají nejhorší pozici z hlediska ovlivňování vládní politiky skrze svého vlastního ministra.

Další kraje jsou na tom $v$ případech, kdy měly alespoň jednoho reprezentanta, podstatně lépe. Kraj Plzeňský byl až na Klausovu II. $(0,88)$ a Špidlovu $(0,85)$ vládu vždy nadreprezentován, at’ už se jednalo o vládu Grosse $(2,06)$, Paroubka $(2,53)$, Topolánka I. $(1,24)$, Topolánka II. $(2,32)$, Nečase $(1,27)$ nebo Sobotky $(1,4)$. Obdobně tomu bylo u Zlínského kraje, který byl zastoupen pouze v pravicových vládách, a to i přes skutečnost, že KDU-ČSL, která nominovala tři ze sedmi ministrů ze Zlínského kraje, byla součástí i levicových vlád. At' už se jednalo o mírnou podreprezentaci v Klausově II. vládě $(0,78)$ a dokonalou reprezentaci $\mathrm{v}$ Topolánkově $\mathrm{I}$. vládě $(1,16)$ nebo nadreprezentaci v Topolánkově II. a Nečasově vládě $(1,45$ a 1,23$)$. Opačnou situaci lze vypozorovat u Olomouckého kraje, který v Sobotkově vládě dosáhl nadreprezentace $(1,27)$ a naopak dokonalého zastoupení v Babišově I. $(1,12)$, Topolánkově I. $(1,07)$ a Grossově $(0,89)$ vládě. O podreprezentaci lze hovořit u Zemanovi $(0,59)$ a Babišovy II. vlády $(0,76)$. Co se týče Jihočeského kraje, ten ve vládě Klause II. $(1,5)$ a Zemana $(1,22)$ dosahoval nadreprezentace, avšak v Babišově I. vládě $(1,1)$ bylo možné označit reprezentaci za dokonalou. V ostatních vládách, at' už Topolánek II. $(0,68)$, Nečas $(0,57)$ nebo Babiš II. $(0,72)$ byl kraj zastoupen nedostatečně. Královéhradecký kraj byl součástí pouze posledních čtyř vlád, přičemž v Nečasově $(0,65)$ a Sobotkově $(0,73)$ byl podreprezentován. V Babišově I. a II. vládě však hodnota míry proporcionality dosahovala 1,28 a 1,67 a kraj byl nadreprezentován. U Pardubického kraje došlo v Klausově II. vládě k výraznější nadreprezentaci $(1,74)$. Tato situace se však již neopakovala, jelikož byl kraj zastupován menším počtem ministrů, než by odpovídalo jeho velikosti, a to v Nečasově $(0,7)$ a Sobotkově $(0,78)$ vládě. V Paroubkově vládě lze navíc hovořit o dokonalé reprezentaci, jelikož hodnota míry proporcionality byla 0,92 . Kraj Vysočina byl podreprezentovaný v rámci Zemanovi $(0,73)$ a Sobotkovy $(0,79)$ vlády. V Paroubkově $(0,9)$, Topolánkově II. $(0,84)$ a Babišově II. $(0,95)$ vládě však lze hovořit o dokonalé reprezentaci.

Ostatní, nejlidnatější, kraje až na Moravskoslezský v Paroubkově vládě měly v každé z vlád alespoň jednoho zástupce. Nejvýraznější nadreprezentace 
dosahovala Praha, jejíž míra proporcionality nabývala v Klausově II. vládě hodnoty 5,06. V dalších vládách však počet osob pocházející z Prahy pozvolně klesal a v posledních dvou vládách se míra proporcionality rovnala ostatním stejně velkým krajům $(1,64$ a 1,78). Obdobný trend lze spatřit i u kraje Jihomoravského, který se v rámci Zemanovi až Paroubkovi vlády pohyboval na hodnotě 1,67 až 2,07 , což značilo výraznější nadreprezentaci a to díky nominaci ministrů z řad ČSSD a KDU-ČSL. V dalších třech pravicových vládách však byl kraj podreprezentován $(0,61-0,76)$ nebo „dokonale reprezentován“ v Sobotkově vládě $(1,04)$. V posledních vládách Andreje Babiše došlo znovu k nadreprezentaci kraje, když hodnota míry proporcionality dosáhla 1,79 či 1,95 a to díky ministrům za ANO 2011.

U Středočeského kraje lze vypozorovat dvě etapy počínající Klausovou II. a končící Topolánkovou II. vládou, ve kterých byl kraj výrazněji podreprezentován, když hodnota míry proporcionality dosahovala 0,42 až 0,73 . Od Nečasovi vlády má kraj výraznějš́i zastoupení ve vládách, jelikož hodnota míry proporcionality dosahovala 1,24 až 1,78 . Určitou výjimkou byla Paroubkova vláda, ve které lze hovořit o „dokonalé" reprezentaci (hodnota 0,82 ). Obdobný trend lze spatřit u Moravskoslezského kraje, který byl až do Sobotkovy vlády podreprezentován, když hodnota míry proporcionality dosáhla 0,3 až 0,77 a v Paroubkově vládě dokonce hodnoty 0 . Až ve dvou vládách Andreje Babiše dosáhl kraj hodnot 1,17 a 1,2, což značí „dokonalou“ reprezentaci. Poslední kraj Ústecký byl součástí pěti z jedenácti vlád, přičemž v rámci dvou pravicových vlád Mirka Topolánka dosahoval nadreprezentace $(1,67$ a 1,56) díky ministrům za ODS. V Sobotkově a Babišově II. vládě naopak dosahoval kraj podreprezentace $(0,49$ a 0,59$)$ a dokonalé reprezentace v Babišově I. vládě $(0,86)$.

$Z$ hlediska celkového počtu nominovaných ministrù ${ }^{12}$ za jednotlivé strany je zrejmé, že strany nominovaly nejvíce ministrů z Prahy, př́padně dalších krajů, ve kterých dlouhodobě zaznamenávaly dobrý volební výsledek (volby.cz (a)). Konkrétně se jedná o nominaci ministrů z Prahy u ODS (20 ze 47), US-DEU (4 z 6), ODA (6 ze 7) a Věci Veřejné (7 ze 7). I přes skutečnost, že Prahu nelze označit jako volební baštu KDU-ČSL (7 z 24), ČSSD (40 z 81) a ANO 2011 (9 ze 41) nominovaly tyto stany většinu svých ministrů taktéž z Prahy. U těchto stran se však projevilo i silné postavení v rámci dalších krajů, at' už Jihomoravského kraje u stran ČSSD (17 z 81), KDU-ČSL ( 7 z 24) a ANO 2011 (9 z 41). Tedy tř́ stran, které měly jako jediné v Jihomoravském kraji hejtmana. Zároveň více ministrů pocházelo ze Středočeského kraje u strany ANO 2011 (9 ze 41), tedy z kraje, ve kterém od roku 2016 do 2020 držely hejtmanský post. Naopak výrazněji se na nominaci ministrů neprojevilo silné postavení v rámci

${ }^{12} \mathrm{~V}$ rámci hodnoty jsou uvedeny i osoby, které byly součástí vícero vlád. 
Prahy u stran TOP 09 + STAN a Strany zelených, u kterých nebylo možné určit převažující kraj mezi nominovanými ministry.

Graf č. 1: Míra proporcionality vlád z hlediska krajů od roku 1996 do 2020

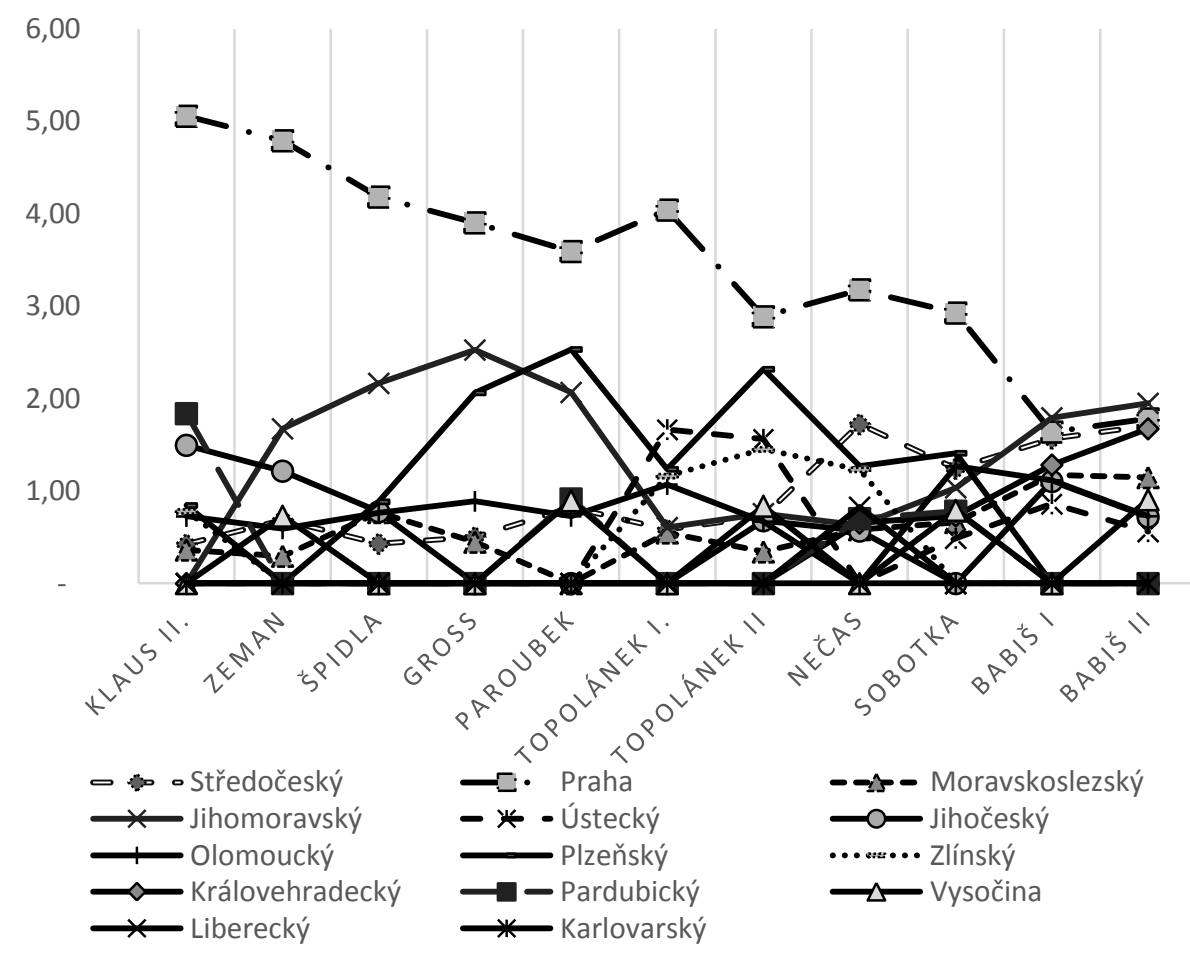

Zdroj: ČSÚ; volby.cz zpracování vlastní

Z hlediska proporcionálního zastoupení dle průměrné hodnoty jednotlivých krajů (viz graf č. 2) je patrná převaha zástupců z Prahy $(3,45)$, př́ípadně mírná nadreprezentace Jihomoravského kraje $(1,38)$. Ideálně zastoupen byl kraj Plzeňský, Středočeský nebo Olomoucký. S podreprezentovanou pozicí je spojen kraj Moravskoslezský $(0,58)$ a Ústecký $(0,47)$ a všechny ostatní kraje. Alarmující je průměrná hodnota u dvou nejmenších krajů, která se rovná téměř nule a lze ji spojit s nemožností ovlivnění vládní politiky skrze své zástupce. $V$ rámci počtu zastoupených krajů není větších rozdílů mezi pravicovými a levicovými vládami ${ }^{13}$. Na počet zastoupených krajů také neměl výraznějš̌́ vliv počet politických subjektů tvořících vládu. $\mathrm{Na}$ druhou stranu je patrné, že snižující se 13 Počet zastoupených krajů ve vládách, Klaus II. (8), Zeman (7), Špidla (7), Gross (6), Paroubek (7), Topolánek (8),
Topolánek II. (10), Nečas (10) a Sobotka (10), Babiš I. (8), Babiš II. (9). 
postavení Prahy mělo efekt i na počet zastoupených krajů, když jejich počet mírně vzrostl z původních 6-8 na 8-10. V budoucím výzkumu tak bude podstatné zjistit, zda dochází $\mathrm{k}$ dalšímu nárůstu počtu zastoupených krajů, případně navýšení významu krajů, které jsou zastoupeny doposud okrajově nebo naopak krajů, které se nyní těší ideálnímu nebo mírně nadreprezentovanému postavení.

\section{Graf č. 2: Průměrná hodnota míry proporcionality krajů v období 1996 -} 2020

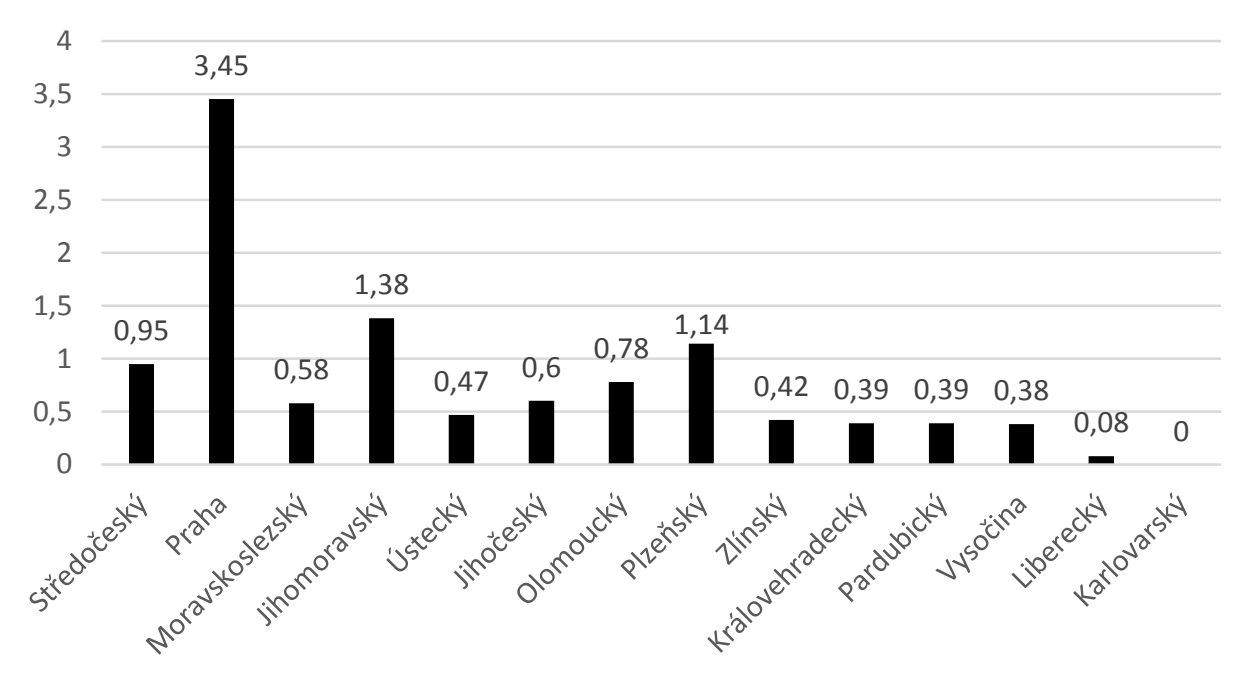

Zdroj: ČSÚ; zpracování vlastní

Z hlediska složení vlád skrze jednotlivé okresy je patrná převaha okresu Praha, který dosahoval v prvních dvou vládách více jak poloviny všech ministrů. V rámci Špidlovi až Topolánkovi I. vlády to bylo mírně pod polovinu všech členů vládního kabinetu, následující vlády kolem jedné třetiny a v rámci Babišovi I. a II. vlády kolem jedné pětiny. Mezi další výrazněji zastoupené okresy patřilo Brno - město, okres, který byl až na Klausovu II. účastný všech sledovaných vlád. Samotné zastoupení však nebylo tak výrazné jako u Prahy, jelikož pouze v Zemanově vládě pocházeli z Brna čtyři ministři, v Babišových vládách ministři tři a ve Špidlově, Topolánkově II., Nečasově a Sobotkově vládě dva ministři. Jeden ministr pocházel $\mathrm{z}$ tohoto okresu v Grossově, Paroubkově a Topolánkově I. vládě. Opakovaného zastoupení skrze jednoho ministra je typické pro okres Olomouc, který nebyl součástí vlády pouze v rámci Nečasovi, Sobotkovi a Babišovi I. vlády. Zajímavým zjištěním je skutečnost, že tři okresy krajských měst (Karlovy Vary, Liberec a Pardubice) nebyly součástí žádné 
vlády. Stejně tak klesá počet ministrů jednotlivých vlád pocházejících z krajských měst (viz tabulka č. 1).

Tabulka č. 1: Počet jednotlivých ministrů v okresech České republiky

\begin{tabular}{lcccc}
\hline \multicolumn{1}{c}{ Vláda } & Počet ministrů & $\begin{array}{c}\text { Z okresů } \\
\text { s krajským měs- } \\
\text { tem }\end{array}$ & Z Prahy & Z ostatních okresů \\
\hline Klaus II. & 22 & $73 \%$ & $59 \%$ & $27 \%$ \\
Zeman & 27 & $85 \%$ & $56 \%$ & $15 \%$ \\
Špidla & 21 & $67 \%$ & $48 \%$ & $33 \%$ \\
Gross & 18 & $61 \%$ & $44 \%$ & $39 \%$ \\
Paroubek & 22 & $55 \%$ & $41 \%$ & $45 \%$ \\
Topolánek I. & 16 & $69 \%$ & $44 \%$ & $31 \%$ \\
Topolánek II. & 24 & $58 \%$ & $33 \%$ & $42 \%$ \\
Nečas & 28 & $61 \%$ & $39 \%$ & $39 \%$ \\
Sobotka & 26 & $50 \%$ & $35 \%$ & $50 \%$ \\
Babiš I. & 15 & $47 \%$ & $20 \%$ & $53 \%$ \\
Babiš II. & 24 & $54 \%$ & $21 \%$ & $46 \%$ \\
\hline
\end{tabular}

Zdroj: ČSÚ; Justice.cz; zpracování vlastní

Z ostatních okresů byl výrazněji zastoupen okres Praha-Západ, a to v šesti $\mathrm{z}$ jedenácti vlád, přičemž ve třech posledních vládách to byli dva, případně tři ministři. Dvěma ministry byl účastný okres Hodonín, a to $\mathrm{v}$ rámci tř́ ze čtyř vlád (Špidlovi, Grossovi a Paroubkovi). Častěji zastoupen byl dále okres Tábor, konkrétněji v sedmi z jedenácti vlád. Ostatních třicet jedna okresů bylo součástí čtyř a méně vlád ve sledovaném období. Lze tedy konstatovat, že kromě tř́i okresů $\mathrm{s}$ krajským městem nebylo zastoupeno $\mathrm{v}$ žádné vládě dalších třicet okresů. $Z$ hlediska jednotlivých krajů a jejich okresů je patrné, že kraj Liberecký a Karlovarský má nejhorší pozici ze všech. V rámci dalších krajů jako Jihočeský, Jihomoravský případně Ústecký pocházeli ministři ze tří, př́ipadně čtyř okresů ze sedmi. U Plzeňského to byly dokonce dva okresy ze sedmi. Specifická situace je u kraje Středočeského, který se dělí na dvanáct okresů, přičemž jedna třetina $\mathrm{z}$ nich neměla svého zástupce ve vládním tělesu. U ostatních krajů nebyly zastoupeny dva či jeden okres, jak dokládá graf č. 3 a obrázek č. 1 . 


\section{Graf č. 3: (Ne)zastoupení okresů z hlediska krajů v ČR}

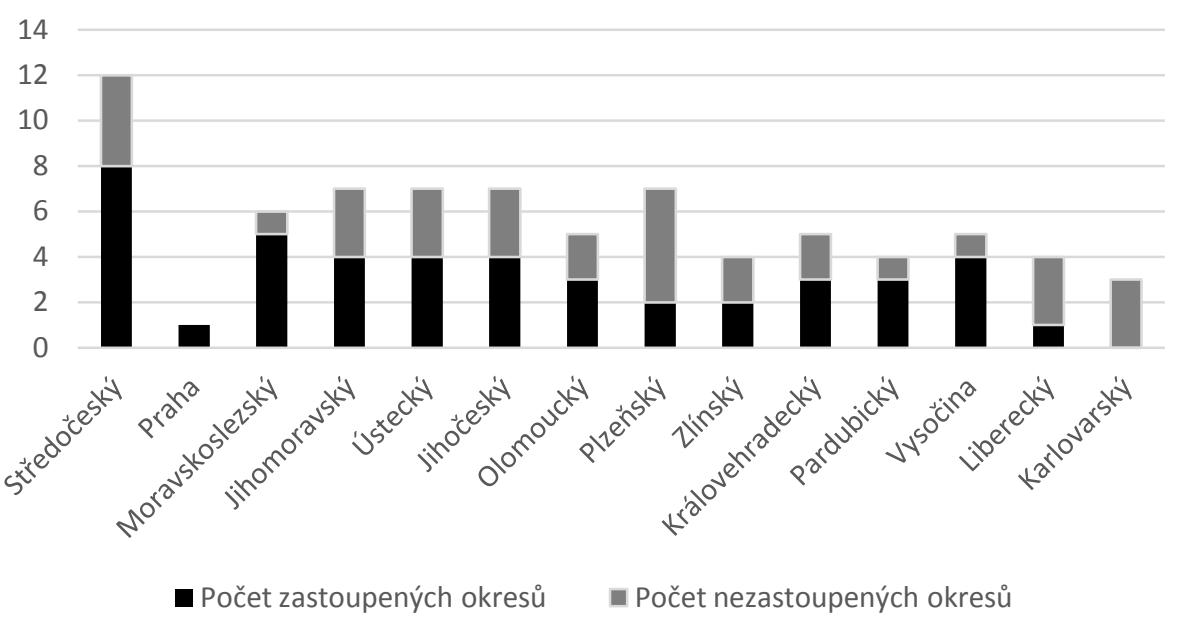

Zdroj: ČSÚ; Justice.cz; zpracování vlastní

Lze tak konstatovat, že se vlády s postupem času neskládají výlučně z center jako je Praha ${ }^{14}$ či Brno, potažmo dalších krajských měst, ale do vlád jsou častěji nominováni ministři z ostatních okresů mimo centra jednotlivých krajů. Zároveň nebyly ve vládách zastoupeny tři krajská města (Liberec, Karlovy Vary a Pardubice), přičemž právě u Pardubic je takové zjištění překvapující, a to i vzhledem ke zjištění, že ostatní okresy z Pardubického kraje svého zástupce v některé $\mathrm{z}$ vlád měly.

\section{Úřednické vlády}

Než se zaměříme na samotnou proporcionalitu vlád Slovenské republiky, je důležité zmínit vynechání třech úruednických vlád České republiky z předchozí analýzy. K tomuto kroku nás vedla skutečnost, že se jednalo o tzv. překlenovací, udržovací vlády, které měly za úkol vyřešit, at' už u vlády Josefa Tošovského nebo Jiř́ho Rusnoka, situaci spojenou s kauzami ODS (financování strany a kauza Nagyová), nebo $\mathrm{v}$ př́padně vlády Jana Fischera zabezpečit pozici v předsednictví Rady EU po vyslovení nedůvěry druhé vládě Mirka Topolánka. Oproti ostatním vládám se navíc jednalo o vlády nestraníků, i když byly osoby navržené politickými stranami ${ }^{15}$. Jednotlivé vlády se však lišily z hlediska zastoupených krajů, at' už počtem nebo zastoupením největších krajů v České republice.

\footnotetext{
14 Pouze v poledních třech vládách došlo k nárůstu počtu osob z okresu Praha-Západ.

15 Konkrétně u Tošovského vlády US, ODA, KDU-ČSL a Fischerovy vlády ODS, ČSSD, SZ.
} 
Obrázek č. 1: Okresy, které měly alespoň jednoho ministra (označeno šedě)

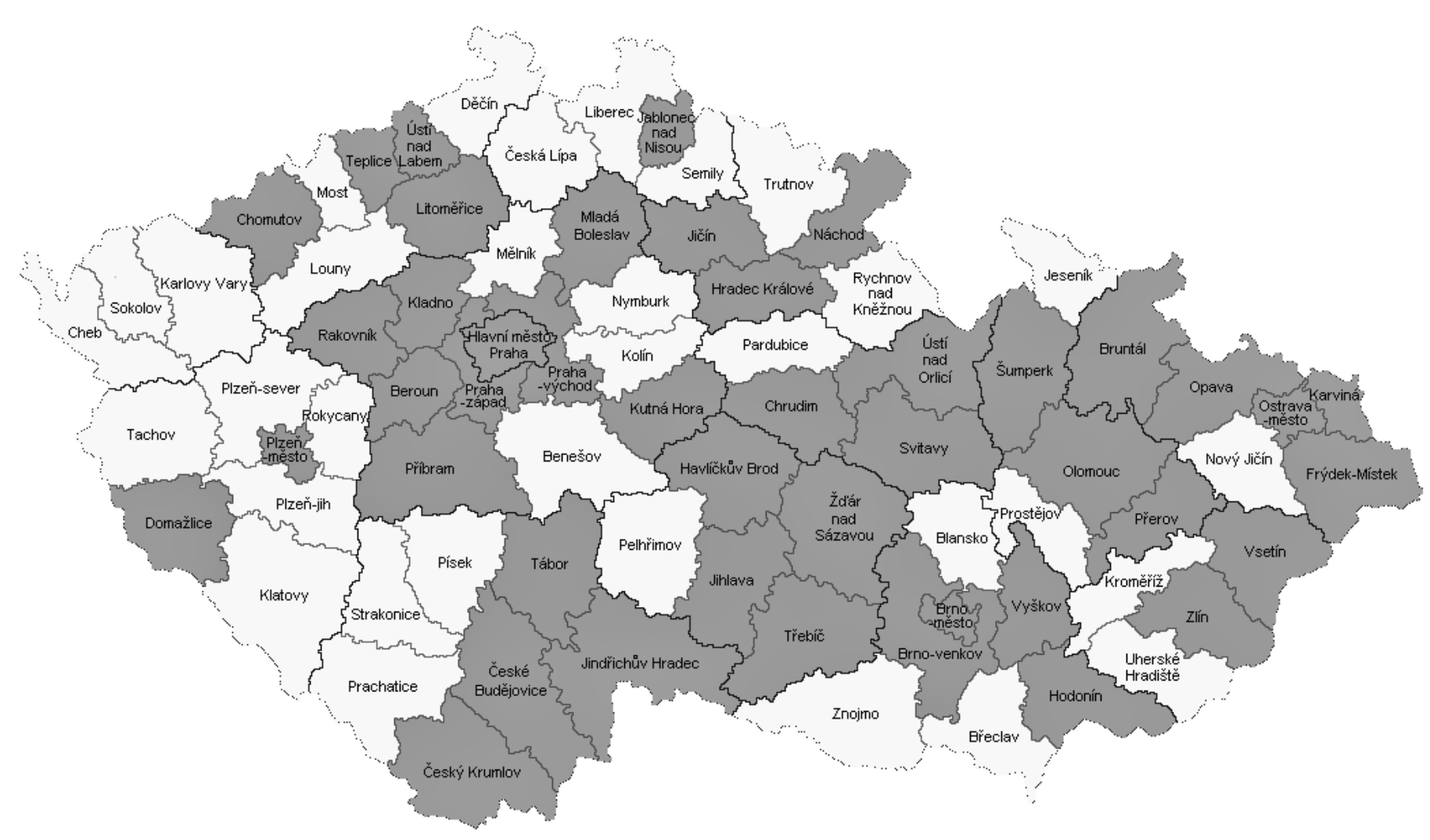

Zdroj: zpracování vlastní 
Tošovského vláda se vyznačovala výraznou převahou osob z Prahy $(5,2)$ a podreprezentaci kraje Středočeského $(0,52)$, na druhou stranu však byl nadreprezentovány kraj Jihočeský $(1,8)$, Pardubický $(2,25)$, a dokonale zastoupený kraj Plzeňský (1). Poslední zastoupený kraj Liberecký měl pouze jednoho ministra, a proto nelze i při hodnotě $(1,3)$, hovořit o nadreprezentaci. $\mathrm{V}$ dalších dvou vládách, at' už Fischerově nebo Rusnokově převažovaly největší kraje České republiky. U vlády Jana Fischera byla nadále patrná převaha Prahy $(5,8)$ a mírná nadreprezentace Středočeského kraje $(1,25)$. Ostatní kraje at' už Moravskoslezský $(0,39)$ nebo Jihomoravský $(0,43)$ neměly dostatečný počet ministrů, a tak se díky jednomu ministrovy vyznačoval dokonalou reprezentací jen kraj Plzeňský $(0,88)$. V rámci vlády Jiř́ho Rusnoka byl patrný pokles výlučnosti Prahy $(3,35)$ a naopak nárůst počtu ministrů pocházejících $\mathrm{z}$ ostatních krajů, at' už Středočeského (2,2), Moravskoslezského (1,1), Jihomoravského $(1,2)$ a Jihočeského $(1,1)$ kraje. Důležitým zjištěním tedy je, že i v rámci úřednických vlád došlo $\mathrm{k}$ umenšení pozice Prahy a nárůstu počtu ministrů $\mathrm{z}$ větších krajů. $Z$ důvodu menšího počtu úřednických vlád však nelze tento trend brát jako konečný a pro potvrzení daného tvrzení by bylo nutné analyzovat další budoucí úřednické vlády.

\section{Míra proporcionality jednotlivých vlád Slovenské republiky od roku 1998}

Jak bylo uvedené výše, slovenské kraje se př́liš neodlišují svojí velikostí a umožňují tak přesnější srovnání. Stejně tak je očekávatelná vyšší nadreprezentovanost Bratislavského kraje, př́ípadně okresu. Absolutní prevevaha Bratislavského kraje však dosahuje v některých momentech absurdních rozměrů.

Dominantní role Bratislavského kraje byla očekávána. Průměrná hodnota míry proporcionality dosáhla úrovně 5,55 , což znamená, že byl kraj pětinásobně více zastoupený vzhledem k počtu obyvatel kraje. Nejvyšší úrovně dosáhl ve vládě Igora Matoviče $(6,62)$ a ve vládě Ivety Radičové $(6,92)$. U obou vlád je možné předpokládat, že vysokou hodnotu způsobila pravděpodobně délka vlád ${ }^{16}$ a skutečnost, že ve vládě nebyly žádné levicové strany. Pravicové strany (SDKÚ, ANO, SaS) měly ve zkoumaném období obecně ministry typicky z Bratislavského kraje, SNS (za Jána Sloty) typicky ze Žilinského kraje. V souvislosti s vládou Ivety Radičové a Igora Matoviče je nutné poukázat na radikálně nerovnoměrné zastoupení. Vláda Radičové byla tvořená pouze zástupci pocházejících ze tř́i krajů, kromě Bratislavského to byl jediný zástupce Banskobystrického a Trnavského. Radičová a její koaliční partneři, tak při sestavování vlády postupovali přesně opačně než čtyři roky před ní Robert Fico.

\footnotetext{
16 Vláda Ivety Radičové byla ve sledovaném období nejkratší vládou, které mandát již skončil, což snižovalo možnost výměny ministrů, kteří by reprezentovali ostatní kraje. Vláda Igora Matoviča je v sledovaném období jen na začátku výkonu svého mandátu.
} 
V době jeho vlády měla Bratislava jednoznačně nejnižší zastoupení, i když i $\mathrm{v}$ této vládě byla více jak trojnásobně nadreprezentovaná. Obdobné nerovnoměrné zastoupení je i u vlády Igora Matoviče, kdy kromě Bratislavského kraje rovněž nalézáme zástupce pouze tř̌ krajů. Kromě Bratislavského jsou to dva zástupci Trnavského kraje a jednoho zástupce má Prešovský kraje.

\section{Graf č. 4: Míra proporcionality jednotlivých krajů}

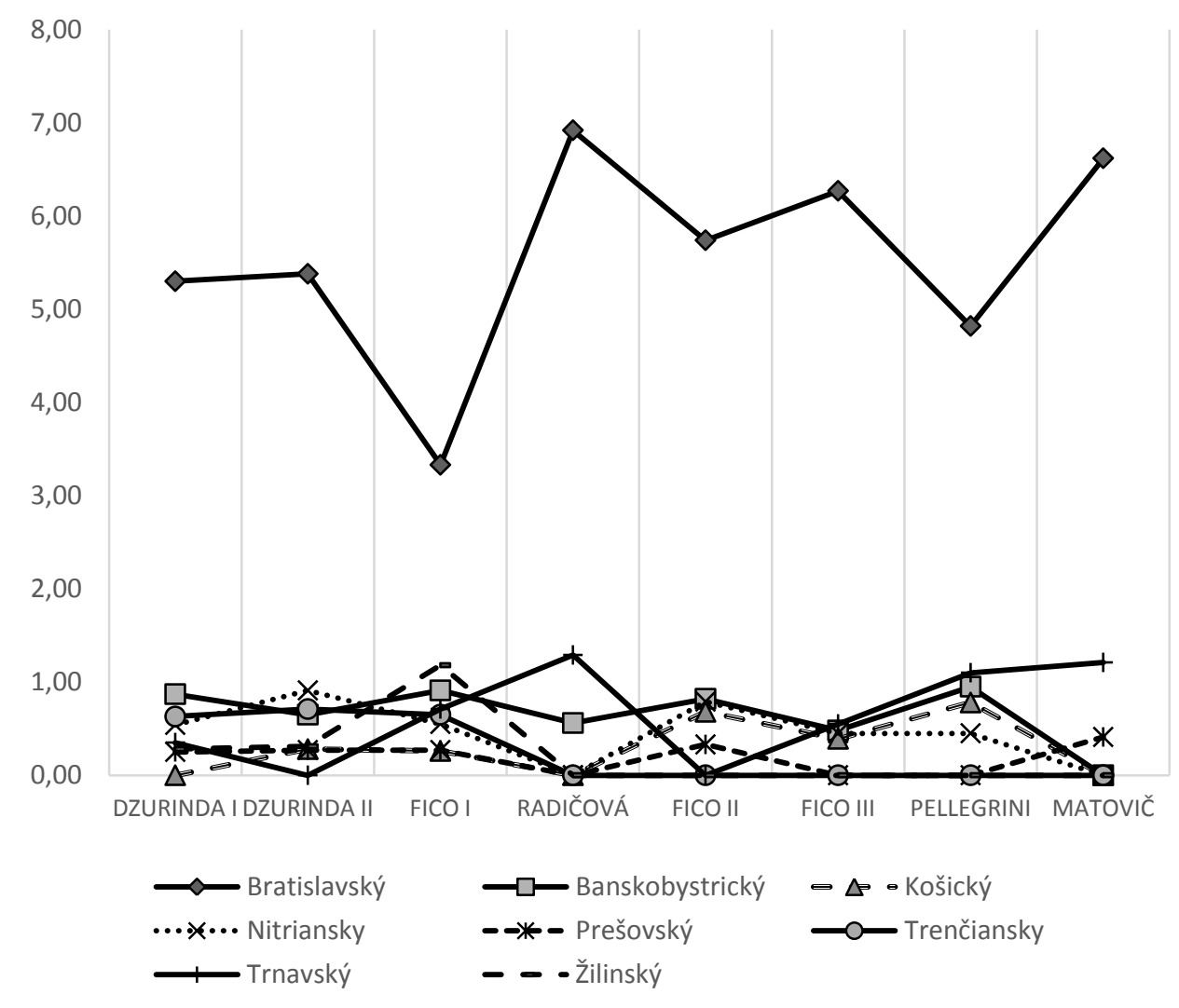

Zdroj: Volby.statistics.sk; Úrad vlády SR, StatDat, zpracování vlastní 
Graf č. 5: Průměrná hodnota míry proporcionality krajů v období 1998 2020

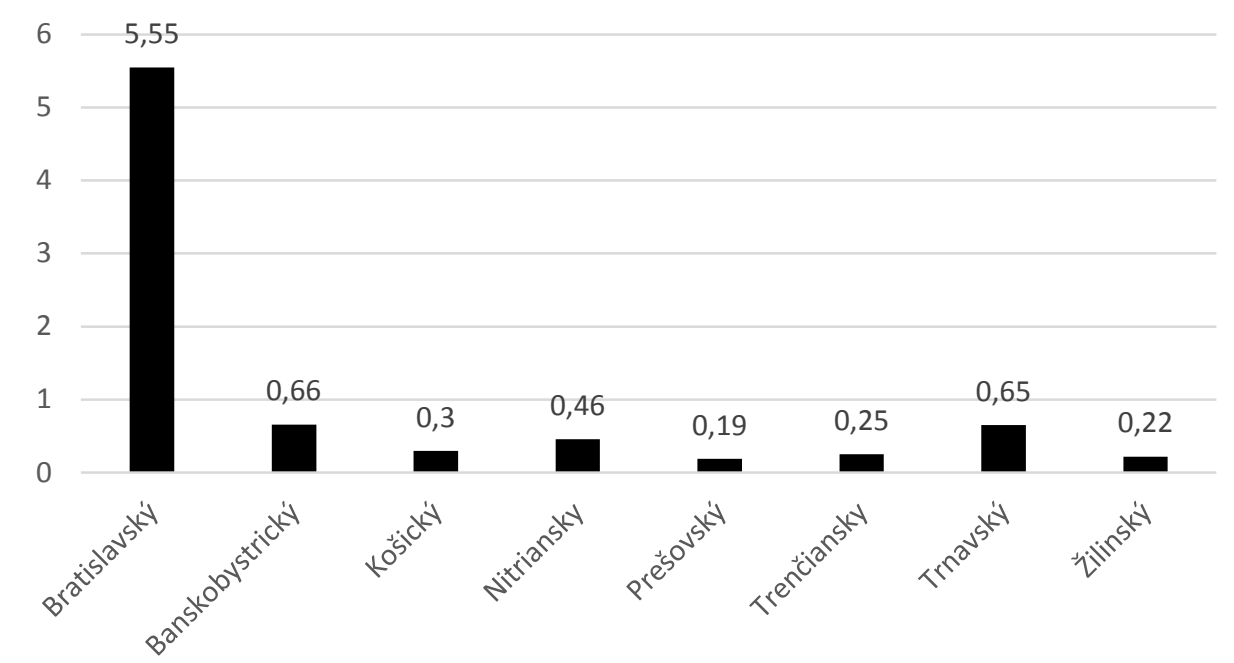

Zdroj:Volby.statistics.sk; Úrad vlády SR, StatDat, zpracování vlastní

Průměrná hodnota míry proporcionality krajů

Zajímavá je situace i z pohledu ostatních krajů. Nejblíže (a přesto poměrně daleko) k ideálnímu proporcionálnímu zastoupení má Banskobystrický a Trnavský kraj (index proporcionality 0,66, resp. 0,65). Banskobystrický kraj byl až do nástupu vlády Matoviče jediným krajem (kromě Bratislavského), který měl zastoupení ve všech vládách. Trnavský kraj se vyznačuje výraznou proměnou v průběhu času, když nulové zastoupení stř́ída s nadreprezentací. To vedlo k tomu, že i když byl kraj dvakrát bez ministerského zastoupení (v druhé Dzurindově a druhé Ficově vládě), zároveň dosáhl třikrát proporcionalitu nad index $1, \mathrm{z}$ toho dvakrát v posledních dvou vládách. V řadě hledisek je paradoxní kraj Košický. I když jsou Košice druhým největším městem, průměrná hodnota zastoupení kraje je pouze 0,3 . Když si zároveň uvědomíme, že Prešovský kraj $\mathrm{s}$ průměrnou hodnotou 0,19 (nejnižší průměr ze všech krajů), stejně jako velmi výrazný nepoměr okresů nominujících alespoň jednoho z ministrů, je poměrně jednoduché pochopit argumentaci o zanedbávání a nedostatečném zastoupení východu. Kromě toho, že má Prešovský kraj nejnižší průměrný index proporcionality, tak i samotné krajské město nenominovalo větší množství ministrů. Od roku 1998 měl okres Prešov jednoho ministra, a to ještě v době Dzurindovi I. vlády, tedy přibližně před osmnácti roky. Celkově byl Prešovský kraj zastoupený v pěti vládách a ani jednou neměl více jak jednoho ministra. Index pro- 
porcionality se tak pohyboval na úrovni $0,3 \mathrm{v}$ závislosti na změnách $\mathrm{v}$ počtu obyvatel. Zajímavé je i to, že každý z pěti ministrů za tento kraj pocházel z jiného okresu. Okres Košice kromě vzpomínané vlády Radičové a Matoviče nebyl zastoupený ani v Dzurindově první vládě. Bylo to paradoxně v roce 1998, kdy byla členem vlády Strana občianskeho porozumenie (SOP) bývalého primátora Košic Rudolfa Schustera. Zarážející je i situace dvou „považských“ krajů, Trenčianského a Žilinského. Ani jeden neměl ministra od konce Ficovi I. vlády, v které byla i Slovenská národná strana. Tento fakt je zvláštní hlavně u Trenčianskeho kraje, jelikož se jedná o dlouhodobou volební baštu SMĚRu. V posledních volbách do Vyšších územních celků v roce 2017 zaznamenal sice SMĚR drtivou porážku (přišel o většinu županů), ale v Trenčianském kraji (spolu s Nitranským) si dokázal udržet výsadní postavení. I přes tuto skutečnost odtud nenajdeme žádného ministra. A podobně je na tom i kraj Žilinský, který je (hlavně díky předsednictví Jána Sloty) spojený s SNS. I když se tato strana účastnila i Ficové třetí a Pellegriniho vlády, deklarovaný odklon od minulosti se týká i míry reprezentativity, jelikož všichni ministři za tuto stranu pod vedením Andreje Danka byli z Bratislavského okresu.

Zaměřme se nyní na proporcionalitu $v$ rámci jednotlivých vlád. První dvě Dzurindovy vlády se vyznačovaly skoro pětinásobným nadreprezentováním Bratislavského kraje, který vždy doplňoval téměř ideálně reprezentovaný $\mathrm{kraj}^{17}$. Poměrně proporční výsledky (na slovenské poměry) dosahoval Trenčianský kraj $(0,63 ; 0,71)$. Naopak nejvíce podreprezentovány byly kraje Prešovský $(0,25,0,27)$ a Žilinský $(0,28$ a 0,31$)$. V obou vládách byli zástupci ze sedmi okresů, v př́ípadě první vlády chyběl reprezentant z Košického kraje, v případě druhé vlády z Trnavského kraje. První Ficova vláda byla naproti tomu nejvíce proporční. Bratislavský kraj dosáhl svého nejnižšího výsledku $(3,33)$, což bylo způsobeno vyšším indexem ostatních krajů. Žilinský kraj $(1,18)$ a kraj Banská Bystrica $(0,91)$ dosáhl ideálního zastoupení, tři kraje (Nitranský $(0,55)$, Trenčianský $(0,65)$ a Trnavský $(0,71)$ zastoupení nedostatečného. Nejvíce podreprezentované však byly dva východoslovenské kraje (Košický 0,26 a Prešovský 0,27$)$. Následující vláda Radičové byla oproti tomu až do nástupu Matoviče v roce 2020 nejméně proporční. Zastoupeny byly pouze tři kraje, přičemž Bratislavský dosahoval do té doby historicky nejvyššího výsledku $(6,92)$, Trnavský byl poprvé nadreprezentován $(1,29)$, přičemž se jednalo o nejvyšší „,mimobratislavskou“ hodnotu ve zkoumaném období. Tuto dvojici doplňoval kraj Banská Bystrica $(0,56)$. Další tři vlády skládal SMĚR. Bratislava zůstala nadále výrazně nadreprezentovaná $(5,74,6,27$ a 4,82) a v každé $\mathrm{z}$ těchto tř̌́ vlád bylo zastoupeno pět krajů. $\mathrm{V}$ druhé vládě Roberta Fica dosáhl Banskobystrický kraj ideální proporcionality $(0,95)$ a kraj Nitranský byl ideál-

\footnotetext{
${ }^{17}$ V první Dzurindově vládě to byl Banskobystrický kraj a v druhé Dzurindově vládě to byl Nitranský kraj, v závislosti na tom, z kterého okresu pocházel zástupce SMK.
} 
nímu zastoupení velice blízko $(0,79)$, stejně jako kraj Košický $(0,68)$. Ve třetí Ficově vládě měl Bratislavský kraj třetí nejvyšší výsledek $(6,27)$ a tři kraje byly na přibližné hodnotě 0,5 , kraj Košický na hodnotě 0,39 . Pellegriniho vláda se zdá být kompromisem mezi oběma př́istupy. Bratislavský kraj byl nadreprezentovaný $(4,82)$, dva kraje (Banská Bystrica $(0,95)$, Trnava $(1,1)$ ) proporční, kraj Košický byl blízko ideálnímu zastoupení $(0,78)$, Nitranský kraj byl na hodnotě 0,45 a tři kraje (Košice, Prešov, Trenčín) nezastoupené. U vlády Igora Matoviče je zřejmá převaha Bratislavského kraje, který je výrazně nadreprezentovaný $(6,62)$, což podtrhuje jeho hegemonní postavení na úkor dalších krajů, jelikož zastoupen je blízko ideálu kraj Trnavský $(1,21)$ a nedostatečně kraj Prešovský $(0,41)$, přičemž ostatní kraje nemají svého zástupce.

Je tak zřejmé, že všechny kraje kromě Bratislavského jsou každé volební období výrazně podreprezentované. Z 56 př́padů (sedm krajů mimo Bratislavský, každý po osmi vládních období), sedmkrát dosáhl některý kraj ideální míry proporcionality (tedy rozsahu 0,8 až 1,2 ). Čtyřikrát se přitom jednalo o Banskobystrický kraj - Pellegriniho vláda $(1,1)$, Druhá Ficova vláda $(0,82)$, První Ficova vláda $(0,91)$ a První Dzurindova vláda $(0,87)$. Ideální proporcionalitu měl také Nitranský kraj v druhé Dzurindově vládě $(0,91)$, Trnavský kraj $(1,1)$ ve vládě Petra Pellegriniho a kraj Žilinský v První Ficově vládě $(1,18)$. Zároveň se pouze ve dvou př́padech stalo, že by i další kraj kromě Bratislavského byl nadreprezentován, konkrétně se jednalo o Trnavský kraj ve vládě Ivety Radičové $(1,27)$ a Matovičově vládě $(1,21)$. S tím souvisí i poslední fakt, že pouze v první vládě Roberta Fica byli prrítomní ministři ze všech krajů. Preferování nejenom Bratislavského kraje, ale i okresů ukazují i výsledky za jednotlivé okresy.

Tabulka č. 2: Počet jednotlivých ministrů v okresech Slovenské republiky

\begin{tabular}{lcccc}
\hline \multicolumn{1}{c}{ Vláda } & Počet ministrů & $\begin{array}{c}\text { Z okresů s krajským } \\
\text { městem }\end{array}$ & Ministři z Bratislavy & Ostatní okresy \\
\hline Dzurinda I & 28 & $78 \%$ & $61 \%$ & $19 \%^{18}$ \\
Dzurinda II & 25 & $76 \%$ & $60 \%$ & $24 \%$ \\
Fico I & 27 & $66 \%$ & $33 \%$ & $30 \%{ }^{19}$ \\
Radičová & 15 & $67 \%$ & $67 \%$ & $33 \%$ \\
Fico II & 20 & $75 \%$ & $40 \%$ & $25 \%$ \\
Fico III & 17 & $71 \%$ & $53 \%$ & $29 \%$ \\
Pellegrini & 17 & $76 \%$ & $47 \%$ & $24 \%$ \\
Matovič & 16 & $81 \%$ & $75 \%$ & $19 \%$ \\
\hline
\end{tabular}

Zdroj: Úrad vlády SR, zpracování vlastní

${ }^{18}$ V první vládě Mikuláše Dzurindy jeden ministr nezastupoval žádný okres, jelikož předtím působil v zahraničí.
${ }^{19}$ V první vládě Roberta Fica jeden ministr nezastupoval žádný okres, jelikož předtím působil v zahraničí. 
Samotné zastoupení hlavního města, krajských měst a ostatních okresů nám ukazuje několik zásadních faktů. $\mathrm{V}$ první řadě, i když byla dominance Bratislavy očekávaná, to, že z hlavního města bude pocházet víc jak polovina všech ministrů ( 89 ze 165), bylo překvapující. Za druhé, výběr slovenských ministrů je zásadně koncentrovaný okolo krajských měst. Až na menší výjimky tři čtvrtiny ministrů (ve zkoumaném období celkově 123 ministrů) v jednotlivých vládách pocházejí právě $z$ osmi krajských měst. $V$ nich žije celkem přibližně pětina obyvatel celé země. Nejnižší úroveň (dvě třetiny) dosáhly krajská města za vlády Ivety Radičové, avšak jednalo se o nejmenší vládu, a i v jejím rámci deset $\mathrm{z}$ patnácti ministrů pocházelo př́mo $\mathrm{z}$ Bratislavy. I $\mathrm{v}$ tomto př́ípadě přitom byli ministři soustředěni hlavně kolem západního Slovenska, přičemž nejvýchodnějším okresem byla Rimavská Sobota. Koncentrace okolo krajských měst je ale v určitém ohledu pochopitelná. Když už strany nominují stranické špičky nebo odborníky, je předpoklad, že budou muset sáhnout bud' po někom z krajské centrály nebo z nejprestižnějších pozic, které se soustředí v krajských městech. I třetí bod navazuje na rozdělení obyvatel a okresů. Ty jsou zastoupeny ze čtvrtiny až pětiny, prričemž dochází (převážně poslední roky) k výběru ministrů blízko hlavního města. Malý okres Senec přispěl s dvanácti ministry stejným dílem jako dva rozlohou největší kraje (Prešovský a Košický) dohromady (ve zkoumaném období měly taktéž 12 ministrů). Koncentrace ministrů ze čtyř okresů sousedících s Bratislavou (Malacky, Senec, Pezinok, Dunajská Streda) v porovnání se zbytkem Slovenska je přitom ještě více udivující. Ze 41 ministrů pocházejících z okresů mimo krajská města bylo hned devatenáct z nich obyvateli čtyř výše zmíněných okresů. Zároveň vidíme výrazný rozdíl v zastoupení ministrů z Bratislavy $\mathrm{v}$ době pravicových a levicových vlád. V období vlády pravice (obě Dzurindovy a Radičové ${ }^{20}$ ) bylo $60 \%$ ministrů z Bratislavy. Jedním z vysvětlení je i to, že SDKÚ byla nejsilnější stranou hlavního města. Oproti tomu levicové vlády byly tvořené zástupci hlavního města přibližně $\mathrm{v}$ polovině př́padů. Výjimku na první pohled tvoří období po volbách 2006, kdy byl z Bratislavy ,jen“ každý třetí ministr, ale výrazná preference krajských měst na úkor zbytku okresních zůstala zachována i tak. Po páté, když v případě Česka deklarujeme postupný odklon od hlavního města, $\mathrm{v}$ případě Slovenska je potřeba být opatrnější. Před nástupem vlády Igora Matoviče se zdálo, že dochází k snižování procenta ministrů z Bratislavy, ale $\mathrm{v}$ tomhle kontextu je potřeba vzít v úvahu i krátkou dobu působení. Po zohlednění předcházejících bodů není rozdíl tak markantní. Dále zůstávají dominantní krajská města, u kterých se míra reprezentace po více jak deset let téměř nezměnila. Po přidání sousedících okresů (kromě Sence, který je označován jako jedno z předměstí Bratislavy) by byla dominance okresů Bratislava ještě

${ }^{20}$ Zůstává otázkou, nakolik je možné současnou vládu Igora Matoviče označit jako pravicovou, když dvě nejsilnější strany - OL'aNO a Sme rodina - je obtížné charakterizovat na pravolevé škále a obecně jsou charakterizování jako populistické. 
Obrázek č. 2: Okresy, které měly ve zkoumaném období alespoň jednoho ministra (označeno šedě)

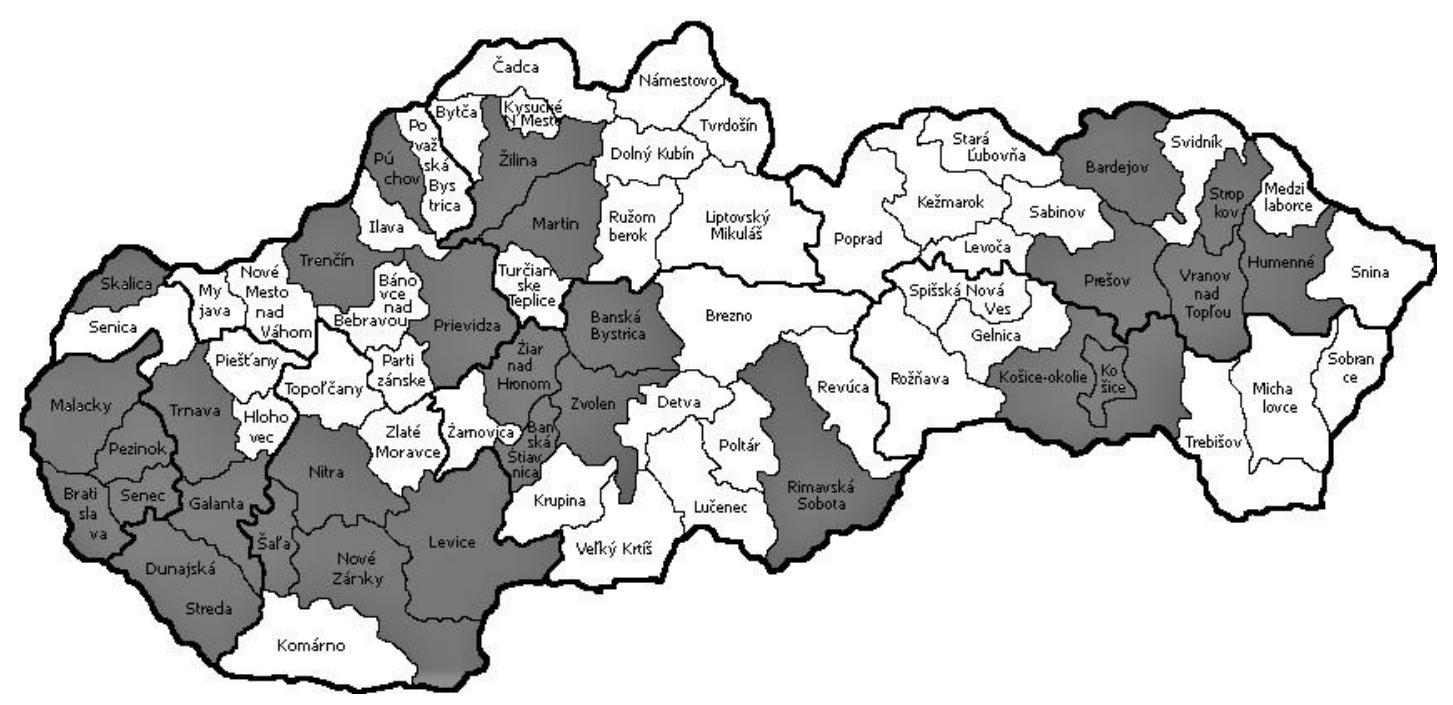

Zdroj: zpracování vlastní

Graf č. 3: Počet (ne)zastoupených okresů podle krajů

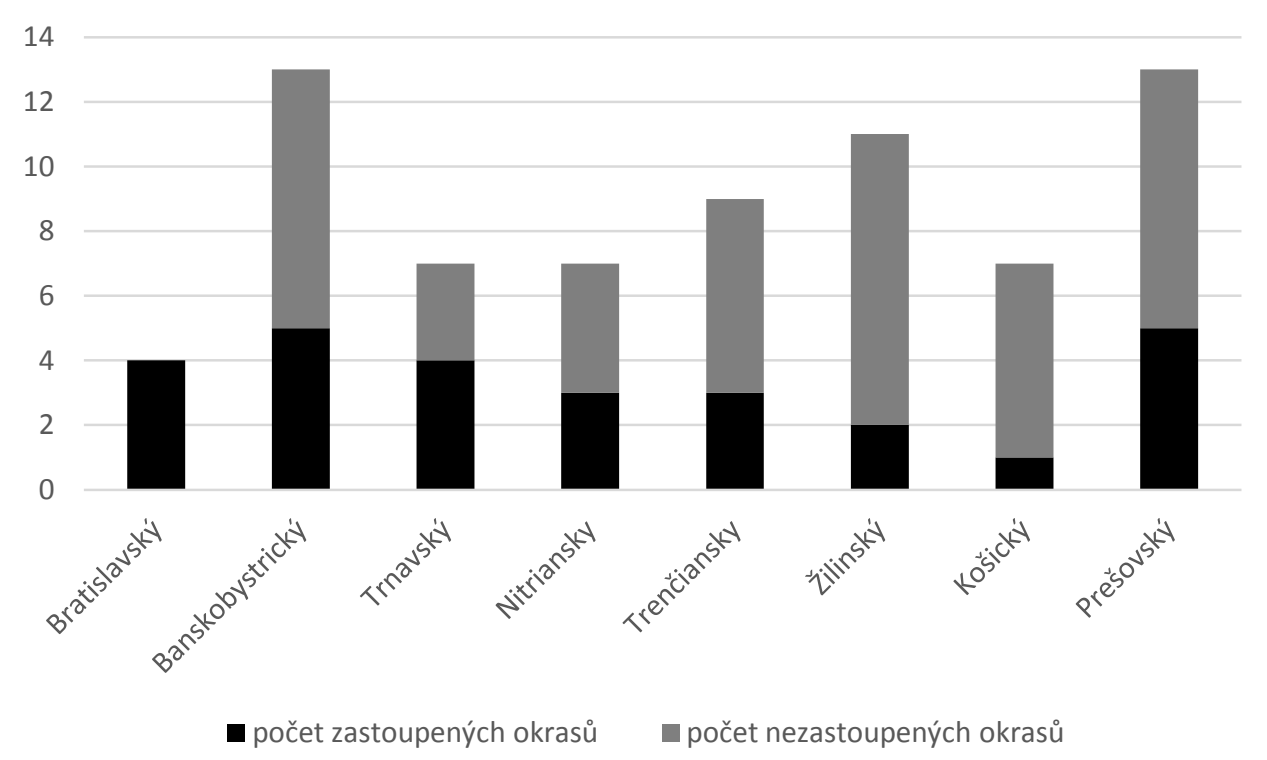

Zdroj: Volby.statistics.sk zpracováni vlastní 
výraznější. Zašesté, i u okresů dochází k výraznějšímu preferování západního Slovenska před východním, jak je patrno z obrázku č. 2. I zde je potřeba upozornit, že ministra mělo 28 okresů, čtrnáct $\mathrm{z}$ nich mělo jednoho ministra a další čtyři jen dva. Jinými slovy, 61 okresů ( 86 \%) mělo přinejlepším dva ministry a ze zbývajících deseti bylo sedm krajských měst (výjimkou byl jenom Prešov, který jako jediný neměl ani dva ministry navzdory statusu krajského města), společně se Sencem, Dunajskou Stredou a Rimavskou Sobotou.

\section{Závěr}

Cílem naší práce bylo zjistit a porovnat rozdílnosti v geografické reprezentativitě dvou zemí, které v minulosti tvořily jeden společný stát. Výzkum ostatních autorů, zejména Mikešové a Kostelecké (2016), jakož i Madleňáka (2019) poukázal na rozdílnosti v geografické reprezentativitě České a Slovenské republiky z hlediska PS ČR a NR SR z čehož vycházela i naše práce zabývající se vládami od roku 1996 (ČR) a 1998 (SR). Rada závěrů, které předložili výše zmínění autoři, se ukázala jako relevantní i v rámci vlád obou zemí. Konkrétně se potvrdilo, že v České republice klesá výlučné postavení Prahy a dalších krajských měst a lze hovořit o proporcionálnějším zastoupení okresů i krajů. Důležitým rozdílem je však přetrvávající nezastoupení dvou nejmenších krajů (Liberecký a Karlovarský) ve většině zkoumaných vlád. Naopak ve Slovenské republice je zřejmá převaha západního Slovenska v rámci krajů i okresů, stejně jako přetrvávající nadreprezentace Bratislavy a dalších krajských měst. Lze tak konstatovat, že složení PS ČR a NR SR může do určité míry předurčovat i složení vlád obou zemí. Na druhou stranu geografickou reprezentativitu vlád výrazně ovlivňuje, jaké strany vládu tvoří a tím pádem i nominují její členy.

Potvrdilo se také, že počet volebních obvodů může mít vliv na míru proporcionality nejen parlamentu, ale i vlád. Slovensko je př́íkladem země s jedním společným volebním obvodem, kde není relativně podstatné, z kterého okresu nebo kraje ministr pochází. Strany nejsou tolik tlačené $\mathrm{k}$ tomu, aby nominovali své představitele z okresů/krajů např́ič celou zemí, jelikož i v rámci parlamentních voleb se počet hlasů bere jako celek, což může mít důsledky v rámci utváření vládní politiky (viz teoretická část). Oproti tomu je Česká republika složena ze čtrnácti volebních krajů, takže jsou strany nuceny vytvářet stejný počet kandidátních listin. $Z$ toho důvodu musí brát v potaz místní identitu svých kandidátů, čímž si vytváří větší počet osobností, které mohou následně nominovat do vládních pozic. Není pritom důležité, zda kandidát př́mo pochází z krajského města, tak jak je tomu na Slovensku. Oproti tomu na Slovensku je důležitá identita hlavního města, která přetrvala $\mathrm{v}$ rámci celého zkoumaného období, což potencionálně motivuje ministry v příštím období zvolit jako své bydliště Bratislavu. 
Náš výzkum ukázal zásadní rozdíly mezi oběma zeměmi. Na začátku zkoumaného období představovaly dominantní úlohu hlavní města, která byla oproti ostatním územím několikanásobně nadreprezentována. Svoji roli v tom mohla sehrát i skutečnost, že se hlavní města stala centrem událostí v listopadu 1989 a i v nynější době je lze označit jako centra politická, kulturní a ekonomická. Na rozdíl od Česka, kde úloha Prahy postupně klesala, se postavení Bratislavy měnilo minimálně a hlavní město (tedy i kraj) si ponechalo svou dominantní pozici. Hodnota proporcionality Prahy jako kraje klesla o více jak polovinu, ale hodnota Bratislavského kraje je na podobné úrovni jako na začátku zkoumaného období. $\mathrm{Z}$ toho vyplývají i ostatní závěry. S klesající hodnotou míry proporcionality kraje $\mathrm{s}$ hlavním městem rostou hodnoty ostatních krajů. Vzhledem $\mathrm{k}$ tomu, že $\mathrm{v}$ případě Slovenska k ničemu takovému nedochází, není možný model proporčního zastoupení krajů. Dalším rozdílem je pravidelná nadreprezentace dalších krajů v rámci České republiky (26 ze 143 př́padů) oproti Slovensku, kde se jedná spíše o výjimky ( 2 z 56 př́ípadů). Obdobně je tomu i v míre ideální proporcionality, která je v rámci České republiky (17 případů v rámci 11 krajů) častější oproti Slovensku (sedm případů v rámci čtyř krajů). Samožrejmě, vliv na to má i samotná velikost kraje, jelikož u menších krajů stačí například jeden zástupce pro ideální míru proporcionality. Stejně tak je rozdílné i zastoupení krajů v rámci zkoumaného období. Některé české kraje (Středočeský, Moravskoslezský, Jihomoravský) vykazují stoupající trend v zastoupení, avšak v rámci Slovenska se nic takového neděje a lze hovořit o statu quo. I při porovnání ostatních krajů je mezi zeměmi velký rozdíl. Typicky Jihomoravský kraj s druhým největším českým městem, se po nadreprezentaci $\mathrm{v}$ době levicových vlád a podreprezentaci za pravicových vlád vrací zpět na předcházející úroveň, což lze potencionálně spojit s návratem levicových stran do vlády. $V$ př́ípadě Košického kraje nezáleží, kdo je u moci, a to i v př́ípadě, kdy je ve vládě strana primátora Košic. Kraj stále patř́ mezi ty s nejnižším indexem proporcionality, a to i přes skutečnost, že jsou Košice druhým největším slovenským městem.

Nejvýraznější odlišnost $\mathrm{v}$ rámci obou zemí spočívá v poměru reprezentativity okresů oproti krajům. Slovensko je výrazně soustředěné (zejména) okolo krajských měst. Nejenže okresy mimo hlavního města disponovaly jenom necelou polovinou všech ministrů, ještě i z nich byla většina koncentrovaná do devíti okresů, $\mathrm{z}$ toho šest okresů $\mathrm{s}$ krajským městem. Vlastního ministra tak měla jen přibližně třetina okresů a víc jak dva pouze devět $\mathrm{z}$ nich (bez Bratislavy). Zastoupení krajských měst se za dvacet let skoro nezměnilo a pohybuje se okolo třech čtvrtin. Přitom Česko je přesný protiklad, jelikož kleslo procento zastoupených ministrů z krajských měst ze $70 \%$ na $55 \%$. V př́ípadě Česka tak dochází $\mathrm{k}$ decentralizaci a na Slovensku nadále zůstává zachována centralizace okolo krajských měst. 
Pro další výzkum by bylo naprosto zásadní a vhodné se zaměřit na to, zda rozdílné zastoupení jednotlivých krajů ve vládě může mít vliv na tvorbu politik vztahujícím se $\mathrm{k}$ jednotlivým krajům. Zda v př́padě, že má kraj výraznou nadreprezentaci, je protěžován v činnosti vlády oproti krajům, které mají malé či nulové zastoupení. Stejně tak lze postupovat i v rámci okresů, kde může být dopad konkrétních politik viditelnější než v rámci krajů.

Petr Dvořák je studentem doktorského studia politologie na Fakultě sociálnich studii Masarykovy univerzity. Na stejné škole vystudoval magisterský studijní program se specializaci na českou politiku. Věnuje se tématům spojeným $s$ volebnim chováním, individuálnimi charakteristikami zvolených politiků at už na krajské či parlamentni úrovni v České republice, ale i dalšich zemí. Okrajově se věnuje tématũm spojeným s komunální politikou.

Milan Podmaník je študentom doktorského štúdia politológie na Fakultě sociálnich studií Masarykovej univerzity v Brne. Na rovnakej univerzite vyštudoval magisterský obor Politológia so špecializáciou na českú politiku. Vedecky sa venuje politizácii štátnej správy, českej a súčasnej slovenskej politike.

Michal Pink je členem katedry politologie, FSS MU. Dlouhodobě se věnuje tématũm spojeným s volbami, prostorovým rozložením volebni podpory a individuálním charakteristikám voliču politických stran. Je autorem a spoluautorem celé řady publikaci v domácím i mezinárodním prostředí, kde pravidelně vystupuje na celé řadě konferencí. Za poslednich pèt let se podilel na řešení projektı̊ zaměrených na kvalitu demokracie a osobnostni charakteristiky vedouci $k$ zisku volené funkce.

\section{LITERATURA}

ATKENSON, L. R., 2003: Not all Cues are Created Equal: The Conditional Impal of Female Candidates on Political Engagement. Journal of Politics 65(4): 1040-1061.

CAMPBELL, R. - COWLEY, P., 2014: What Voters Want: Reactions to Candidate Characteristics in a Survey Experiment. Political Studies 62(4): 745-765.

CAUL, M., 1999: Women's Representation in Parliament: The Role of Political Parties. Party Politics 5(1): 79-98.

ČSÚ - Český statistický úřad. Počet a věkové složení obyvatel k 31. 12. - vybrané území. https://vdb.czso.cz/vdbvo2/faces/cs/index.jsf?page=vystup-objekt-parametry $\& z=T \& f=T A B U L K A \& k a t a l o g=30845 \& p v o=D E M 02 \& s p=A \& f i l t r=G \% 7 E F \_M \% 7 E F \_Z \% 7$ EF_R\%7EF_P\%7E_S\%7E_U\%7E401_null_\&u=v68_VUZEMI_101_40703\&str=v68

DOVI, S., 2017: Political Representation. In: The Stanford Encyclopedia of Philosophy. Ed. Edward N. Zalta. Stanford: Stanford University. http://plato.stanford.edu/entries/political-representation/

DOVI, S. 2010: Measuring Representation: Rethinking the Role of Exclusion. APSA 2010 Annual Meeting Paper. https://ssrn.com/abstract=1642537 
GROSSMAN, G. M. - HELPMAN, E., 2005: Party Discipline and Pork-Barrel Politics, July 2005: Harvard Institute for Economic Research Discussion Paper No. 2075. http://dx.doi.org/10.2139/ssrn.754085

GOODIN, R., 2004: Representing Diversity. British Journal of Political Science 34(3): 453-468.

HÁNA, D., 2013: Porcování ministerského medvěda: souvislost mezi poslaneckými a ministerskými dotacemi v Česku v období 2004 - 2012. Politologická revue 19(2): 76-92.

Justice.cz. Dostupné na: https://justice.cz/

LATNER, M. - MCGANN, A., 2005: Geographical Representation under Proportional Representation: The Cases of Israel and the Netherlands. Electoral studies 24(4): 709-734. DOI: 10.1016/j.electstud.2005.02.007

KEY, V. O., 1949: Southern Politics in State and Nation. Knoxville: Alfred A. Knopf.

KROOK, M. L. - O'BRIEN, D. Z., 2010: The Politics of Group Representation: Quotas for Women and Minorities Worldwide. Comparative Politics 42(3): 253-272.

MADLEŇÁK, T., 2019: Geografická reprezentativita poslancov NR SR zvolených $\mathrm{v}$ podmienkach jedného volebného obvodu. Sociológia 51(5): 483-501. DOI: https://doi.org/10.31577/sociologia.2019.51.5.22

MANSBRIDGE, J., 1999: Should Blacks Represent Blacks and Women Represent Women? A Contingent "Yes". The Journal of Politics 61(3): 628-657.

MIKEŠOVÁ, R. - KOSTELECKÝ, T., 2016: Geografická reprezentativita poslanců zvolených do Poslanecké sněmovny českého parlamentu za první republiky $(1918$ - 1938) a po roce 1989. Středoevropské politické studie 18(4): 354-380. doi: http://dx.doi.org/10.5817/CEPSR.2016.4.354

PHILLIPS, A., 1998: Democracy and Representation: Or, Why Should It Matter Who Your Representatives Are? In Feminism and Politics. Oxford: Oxford University. s. 224-240.

PITKIN, H., 1972: The Concept of Representation. Berkeley: University of California Press, s. 323.

POWELL, G. B., 2004: Political Representation in Comparative Politics. Annual Review of Political Science 7: 273-296. doi:10.1146/annurev.polisci.7.012003.104815.

SQUIRES J., 1996: Quotas for Women: Fair Representation? Parliamentary Affairs 49(1): 71-88.

StatDat. Počet obyvatel'ov podl'a pohlavia - SR, oblasti, kraje, okresy, mesto, vidiek (ročne). http://statdat.statistics.sk/cognosext/cgi-bin/cognos.cgi?b_action=cognos Viewer\&ui. action=run\&ui.object=storeID \%28\%22i362DCE4D88EC4E13A9EE8526B286D18B\%22\% 29\&ui.name $=$ Po $\%$ c $4 \% 8$ det $\% 20$ obyvate $\%$ c4\%beov $\% 20$ pod $\%$ c $4 \%$ bea $\% 20$ pohlavia $\% 20-\% 20$ SR $\% 2 \mathrm{c} \% 20$ oblasti\%2c\%20kraje\%2c\%20okresy \%2c\%20mesto $\% 2 \mathrm{c} \% 20$ vidiek $\% 20 \% 28$ ro\% c4\%8dne $\% 29 \% 20 \% 5$ bom $7102 \mathrm{rr} \% 5 \mathrm{~d} \&$ run.outputFormat=\&run.prompt=true\&cv.header=fals e\&ui.backURL=\%2fcognosext $\% 2 \mathrm{fcps} 4 \% 2$ fportlets $\% 2 \mathrm{fcommon} \% 2 \mathrm{fclose} . \mathrm{html} \&$ run . outputLocale $=$ sk

Úrad vlády SR, 2020: História vlád SR. https://www.vlada.gov.sk//historia-vlad-sr/.

Vláda České republiky, 2020: Historie minulých vlád. Přehled vlád ČR. https://www.vlada.cz /cz/clenove-vlady/historie-minulych-vlad/prehled-vlad-cr/1993-2007-cr/

VODA, P. - PINK, M., 2009: Kandidáti v poslaneckých volbách. Analýza preferenčního hlasování ve volbách do PS PČR v roce 2006. Středoevropské politické studie 11(2-3): 163-180.

Volby.cz: Volby do poslanecké sněmovny 1996 - 2017. https://volby.cz/

Volby.cz (a): Volby do Poslanecké sněmovny 1996 - 2017. Výsledky hlasování za jednotlivé kraje. https://volby.cz/

Volby.statistics.sk: Vol'by do Národnej rady Slovenskej republiky 1994 - 2006. http://volby.statistics.sk/ 